\title{
Diseasing the City: Colonial Noir and the Ruins of Modernity
}

\author{
Robert Peckham
}

\section{Allegory in a Time of Waiting}

Writing during the dissolution of the Soviet Union, Susan Buck-Morss reflected on the demise of what, borrowing from Walter Benjamin, she termed the dreamworlds of industrial modernity. Twentieth-century political ideologies, be they socialist, capitalist or fascist, had striven to transform and transcend the natural world through material power by building mass utopias. Although they claimed "to rule in the name of the masses," in fact, they had constructed an undomesticated "wild zone of arbitrary, violent power," obscured from public scrutiny (Buck-Morss 2002: 4). The challenge for Buck-Morss was to consider, not the political effects of post-Cold War fragmentation, but rather "the fundamental shift in the historical map [which] shattered an entire conception of the world" (2002: x).

A decade - two since the collapse of the USSR - may be the right critical distance from which to reassess the shattered remnants of modernity's dreamworlds that continue to haunt contemporary culture in the blown-out cityscapes of disaster movies, such as the remake of Richard Matheson's 1954 novel I Am Legend (2007). There, disease is a symptom of - and a catalyst for - the city's ruin and restoration. The future resembles a pre-modern past in which the hunter-gatherer protagonist stalks and is stalked through the wild canyons of Manhattan, paradoxically recuperating, in the midst of the shattered metropolis, indigenous meanings buried in the toponym: 'the island of hills.'

It may be time, too, to reconnect neo-noir visions of wrecked cityscapes with earlier responses to catastrophes and in so doing to resituate discussions of noir within the fragmented territory of industrial modernity, in the ruins of the colonial city. Noir, at least as a genre of political engagement, took shape in a world that had experienced the Nazi blitzkrieg, the holocaust, occupation, and the disintegration of empire - as well as the atomic bombs on Hiroshima and Nagasaki, which, as Albert Camus noted, marked "the end of ideologies" (Camus 1989: 53). In this post-war environment, history no longer appeared to furnish a framework for elucidating the present, nor did it provide guideposts for the future.

In Jean-Paul Sartre's words, the post-WWII present resembled "a labyrinth of hallways, doors, and stairways that lead nowhere, innumerable signposts that dot routes and signify nothing" (Quoted in Polan 1986: 252). Or as Sartre noted in his reflections on Henri Cartier-Bresson's photographs taken between 1948 and 1949 as China passed from old world to revolutionary republic: an "intermediate phase, a gelatinous duration equally distant from History and repetition: the time of waiting" (Sartre 2001: 26). Noir can perhaps best be understood, in this context, as a form of allegory in the sense identified by Benjamin in his account of baroque tragedy (1928); a form preoccupied with death, anguish and alienation:

The baroque writer and the modern writer are both anti-romantic in their pessimistic conviction that meaning has fled from the earth and left behind only the 'signs' of things unreadable - a script we can no longer decipher with confident clarity (Kearney 1988: 156).

Noir, then, as allegory in a time of waiting; as a means of "[coming] to terms with dreamworlds at the moment of their passing" (Buck-Morss 2002: x). 


\section{The Ruined Future}

In August 1946, Nino Frank remarked that a new generation of Hollywood auteurs was eschewing "museum objects" in favour of grittier, criminal adventures or "films 'noirs" (Naremore 1998: 15-16). In the same year, Sartre returned to the US, writing about his experiences of urban cityscapes in a series of essays including 'American Cities,' published in Le Figaro, and 'New York, Colonial City,' originally published in Town and Country. Sartre's reactions were contradictory: in part, he celebrated the newness and freedom of the American urban life; in part, he bemoaned the uniformity of planning and the conformity of American suburban life. Contemplating the Empire State and the Chrysler Building in Manhattan, Sartre observed: “...suddenly it occurs to me New York is on the point of acquiring a history and that it already has its ruins" (2008: 133). For Sartre, looking upon this "landscape of modernity" (Ward and Zunz 1992), the future appeared ruined before it had begun, whilst the past was still waiting to happen. Or, to quote from William Faulkner's 1951 Requiem for a Nun - a writer whose work had influenced Sartre's own (Sartre 1946) - "The past is never dead. It isn't past."

New York, for Sartre, of all US cities, seemed to carry the seeds of its own destruction. It was an idea of selfannihilation amplified by E. B. White in his short but evocative book Here is New York (1949), which reverberates uncannily in the aftermath of the September 112001 attacks on the Twin Towers of the World Trade Center:

A single flight of planes no bigger than a wedge of geese can quickly end this island fantasy, burn the towers, crumble the bridges, turn the underground passages into lethal chambers, cremate the millions... All dwellers in cities must live with the stubborn fact of annihilation (Quoted in Dimendberg 2004: 43).

The strength of the city - its very gridiron, rational orderliness and its engineered foundations - appeared constructed as a vehicle for destruction. Similarly, the city felt to Sartre, at times, like a concentration camp (in 1940 Sartre had been captured by the Germans and transferred to Stalag 12D), planned expressly to annihilate and be annihilated.

What should one make of these reflections? The vision of a dreamworld ruined before it has lived. A future that is past before the past is past. New York as ground zero, where the "evil" heat "crashes down on the city like an atomic bomb" (Sartre 2008: 128). An answer may lie in Sartre's characterization of New York as "a colonial city" "an immense, malevolent space":

Even in the depths of my apartment, I suffer the depredations of a hostile, muffled, mysterious Nature. I have the impression of camping in the heart of a jungle teeming with insects. There is the moaning of the wind, the electric shocks I get each time I touch a doorknob or shake a friend's hand, the cockroaches running round my kitchen, the elevators that make my stomach heave, the inextinguishable thirst that rages from morning till night. New York is a colonial city, a camp site (Sartre 2008: 128).

Sartre's colonial city can be read within the broader context of his life-long interest in racism and colonial politics, including the wars in Morocco, Algeria and China (Lamouchi 1996; Smith 2009). For Sartre, American cities reflected their origins as European 'encampments' or colonial 'outposts' in a vast, uncharted continent:

As for the Americans, it was not their cruelty or pessimism which moved us. We recognized in them men who had been swamped, lost in too large a continent, as we were in history, and who tried, without traditions, with the means available, to render their stupor and forlornness in the midst of incomprehensible events (Sartre 1966: 156).

It was this swamping by the hinterland, according to Sartre, which, in spite of all their architectural monumentality, gave US cities a sense of contingency or provisionality. By the same token, the modernity of New York with its gridlike, inorganic uniformity, served to heighten, rather than to diminish, the 'natural' forces ranged against it. It was not "the shock of the new" so much as the shock of raw electricity or "hostile nature" attacking through the chinks of the techno-dreamworld. At the same time, the city diseased. There was, Sartre observed, such a condition as "New York sickness,' akin to sea sickness, air sickness or altitude sickness" (2008: 121). The city made Sartre "nauseous" and wracked him with "inextinguishable thirst," not unlike the "sweetish sickness" that afflicts the historian Antoine Roquentin in La Nausée (1938). Indeed, illness, for Sartre, was a concomitant of writing - of modern writing: "The language of poetry rises from the ruins of prose" he declared in a footnote to his essay "What is Writing? (Sartre 2000: 115). Or as Raymond Borde and Étienne Chaumeton expressed it in Panorama of American Film Noir: "In this incoherent brutality, there is the feeling of a dream" (1955/2002: 10-11). 
Sartre was not alone in his sickness. On 25 March 1946 another French writer docked at New York on a tour of the northeastern US and Canada, under the auspices of the Cultural Relations Section of the French Ministry of Foreign Affairs: Albert Camus. By coincidence, the head of French Cultural Services in New York was the anthropologist Claude Lévi-Strauss (Lottman 1979: 378). In fact, it had been Camus who, at the helm of the magazine Combat, had supported Sartre's first trip to the US in 1944-5 (Reid 1997: 615). Approaching the harbor in the freight ship Oregon, Camus was struck by New York's 'inhumanity': "The order, the strength, the economic power" which emitted a "perfume of iron and cement." Everyone, he noted, "looks like they've stepped out of a B-film" (Camus 1989: 32-33). As for Sartre, so too for Camus, New York made him ill: he toured the city in a feverish state. In 1946 Camus had good reason to have disease on his mind, having been working on La Peste (published in 1947): a novel by a pied-noir about a colonial city overcome by bubonic plague - la peste noire - another kind of blackness. His New York journal is punctuated with reflections on the book, as when he compares the recent US bombing of imperial Japan (Hiroshima and Nagasaki in August 1945) with the plague-ravaged colonial city of Oran, the setting of his novel: "In the American newspapers: A weapon more frightening than the atomic bomb. 'In certain places in the Middle Ages the black plague killed 60\% of the population"' (Camus 1989: 49). As Camus noted in a letter of June 1946 to Janine and Michel Gallimard, New York reminded him of Oran and the Americans resembled the Algerian colonists with whom he could no longer live: [Les Américains] ressemblent tant à nos colons d'Algérie, mais je ne plus vivre avec eux (Quoted in Todd 1996: 411).

As for Sartre, so too for Camus, New York seemed to be over before it had begun and its hyper-modernity felt strangely antiquated:

Manhattan. Sometimes from beyond the skyscrapers, across the hundreds of thousands of high walls, the cry of a tugboat finds you in your insomnia in the middle of the night, and you remember that this desert of iron and cement is an island (1989: 51).

Watching workmen excavating foundations between skyscrapers, Camus was filled with an overwhelming "feeling of something prehistoric." The skyscrapers were "monoliths" that rose up in the grey haze "whitened like the immense sepulchers of this city inhabited by the dead. Through the rain one sees the sepulchers sway on their foundations" (Camus 1989: 52). In the same way, Sartre could not think of skyscrapers "without melancholy." They were "historical monuments, witnesses to a bygone age" and as such they belonged to the architecture of the past, rather than to the future (Sartre 2008: 132-133).

\section{Sickness and the Locus of Noir}

In perhaps one of his most well-known formulations Anthony King in Global Cities suggested that: "Colonial cities can be viewed as the forerunner of what the contemporary capitalist world city would eventually become." For King, colonial cities were the places where the "representatives and institutions of industrial capitalism confronted ethnically, racially and culturally different pre-industrial and pre-capitalist societies at any significant scale" (King 1990: 38).

It is in these ethnically and racial mixed 'colonial' cities where material power strives to transform the natural world, but where the capitalist matrix sits imperfectly on a pre-capitalist society, that Buck-Morss' undomesticated terrain of "arbitrary and absolute" power becomes visible. This is the locus of noir: junks against a crenellated backdrop of skyscrapers; slum shacks beside walls of glass, steel and concrete; teeming markets alongside floodlit corporate headquarters. As Poshek Fu and David Desser inquire: "Hong Kong: East or West, Chinese or British, traditional or modern, colonial or postcolonial? Issues of identity continue to plague the territory..." (2000: 9). In this "wild zone" of power, identity is recast as pathology: the colonial city is always and ineluctably plagued.

Of course, the diseased colonial city features in classic noir. In Elia Kazan's Panic in the Streets (1950), for example, set in New Orleans where the autopsy of a man murdered by a gangster ('Blackie') in a gambling scuffle establishes that he is infected with a deadly disease: pneumonic plague. The protagonist, Dr. Clinton Reed, is a US Public Health Service officer on the hunt to trace the killer who threatens to spark a deadly epidemic. Or in Earl McEvoy's The Killer that Stalked New York (1950), where a jewel thief imports smallpox to the city from Cuba.

What connects these plague movies with Sartre and Camus? For one, disease in these narratives of urban infection can be read as a political allegory. In La Peste disease functioned, at least on one level, as a metaphor for 
fascism in Vichy France. As Camus wrote in his essay 'Contagion,' published in Combat, racism was a form of lethal infection (Camus 1965: 321-323). Moreover, for Sartre, 'illness' was "the only form of life possible in capitalism," a "shared contraction" consequent upon the atomizing forces of industrial modernity as he expressed it in the 1972 preface to Wolfgang Huber's Socialist Patients' Collective: Turn Illness into a Weapon (Sartre 1987).

In Kazan, disease suggests the witch-hunts against communists in McCarthy America, with the pneumonic plague expressive of latent fears about ideological infection and the correlative race to contain disease. By the early 1950s, McCarthyist hysteria had spread across the US, with Congress passing restrictive laws, including the Internal Security Act of 1950, which prohibited the entry or settlement of communist (or former communist) immigrants. As J. Edgar Hoover asserted in 1947:

It [Communism] reveals a condition akin to disease that spreads like an epidemic and like an epidemic a quarantine is necessary to keep it from infecting the Nation (Quoted in Wald 2007: 175).

Significantly, disembarking at New York, a feverish Camus was himself interrogated by immigration inspectors for his links with the Communist Party (Lottman 1997: 399).

\section{Conclusion: Black Rain}

The diseasing city; the colonial encampment; the ruins of a future; the colonial city pushed to the extremes of rationality where coherence tips into incoherence; the uniform but culturally-mixed metropolis (Camus was fascinated by the noirs: black bars and black music and, in Manhattan, the boisterous clubs of the Bowery). These elements, explored by both Sartre and Camus in their forays to New York in 1946 were and remain crucial to noir.

Much has been written about Camus' partial descriptions of colonial Algeria. Edward Said has argued that in Camus' writing the French colonial presence is assumed to be enduring, whilst the indigenous Algerian population is stripped of its humanity and reduced to a cipher (Said 1993: 169-185). But as David Reid has argued, there are continuities between Camus' vision of colonial New York and his descriptions of the ruins at Tipasa and Djemila in Algeria (Reid 1997). There, too, clambering among the ancient remains, Camus glimpsed the inevitability of every empire's ruin.

Camus' journal entries and letters of his visit to New York, later written up as 'The Rains of New York' (1947), evoke this sense of entrapment and stifling repetition, which are underscored by the relentless downpour:

Rain on New York. It flows untiringly between the high cement walls. The taxi's rapid and monotone windshield wipers sweep a water which is incessantly reborn - bizarre feeling of remoteness. Impression of being trapped in this city, that I could escape from the monoliths that surround me and run for hours without finding anything but new cement prisons, without the hope of a hill, a real tree, or a bewildering face (Camus 1989: 51-52).

This sodden evocation of New York, described in terms of both its ancient-ness ('monoliths') and its newness ('concrete') anticipates Camus' essay 'Return to Tipasa' (1953), a town on the Algerian coast famous for its Roman ruins, which Camus wandered around in the rain, watching ancient sarcophaguses fill with black water - les sarcophages pleins d'eau noire. As in his early visit to the ruins of Djemila in 1936, at the very moment that Benito Mussolini was constructing his version of a mass utopia that drew on the glories of Rome, Camus was acutely aware of the futility of such worldly claims to power. As the tour guide invoked a 'conventional' history of the site, Camus reflected on the paradox: "the ruins of their civilization are the very negation of their ideal." Or as he concluded: "The world always finishes by conquering history" (Quoted in Reid 1997: 611).

The language of the future past and the shattered afterlife of a dreamworld driven to catastrophe, where the feverish narrator struggles to recuperate elusive meaning: this is one contribution of wartime and post-war French philosophy to the discourse of noir as it developed, particularly from the 1970s, working its way back into the plagued cities of late twentieth-century and early twenty-first century neo-noir where the future coexists with its ruins. Furthermore, this French politico-philosophical noir persists in Mike Davis' urban excavations of the future, for example, and in his accounts of the slum-cities of the contemporary world with their suppurating "ecologies of fear" (Davis 1990, 1998, 2005, 2006; Davis and Monk 2007). Global cities are today haunted by the specter of pandemics - deadly infections produced by a reconfigured capitalism, which may be making visible another terrain of post-colonial noir. 


\section{References}

Borde, Raymond and Étienne Chaumeton 2002 (1955) A Panorama of American Film Noir, 1941-1953, trans. Paul Hammond. San Francisco: City Lights Books.

Buck-Morss, Susan 2002 Dreamworld and Catastrophe: The Passing of Mass Utopia in East and West. Cambridge, MA: MIT.

Camus, Albert 1989 American Journals, trans. Hugh Levick. London: Hamish Hamilton.

1978 Journaux de Voyage, ed. Roger Quilliot. Paris: Gallimard. 1965 Essais. Paris: Gallimard, Bibliothèque de la Pléaide.

Davis, Mike 2006 Planet of Slums. London and New York: Verso.

2005 Monster at Our Door: The Global Threat of Avian Flu. New York and London: The New Press.

1998 Ecology of Fear: Los Angeles and the Imagination of Disaster. New York: Metropolitan Books.

1990 City of Quartz: Excavating the Future in Los Angeles; photographs by Robert Morrow. London: Verso.

Davis, Mike and Daniel Bertrand Monk, eds. 2007 Evil Paradises: Dreamworlds of Neoliberalism. New York and London: New Press Distributed by W.W. Norton \& Co.

Dimenberg, Edward 2004 Film Noir and the Spaces of Modernity. Cambridge, MA: Harvard University Press.

Fu, Poshek and David Desser 2000 The Cinema of Hong Kong: History, Arts, Identity. Cambridge: Cambridge University Press.

King, Anthony 1990 Global Cities. London: Routledge.

Lamouchi, Noureddine 1996 Jean-Paul Sartre et le Tiers Monde: Rhétorique D'un Discours Anticolonialiste. Paris: L'Harmattan.

Lottman, Herbert R. 1997 (1970) Albert Camus: A Biography. London: Axis Publishing.

Naremore, James 2008 (1998) More Than Night: Film Noir in Its Contexts. Berkeley, CA: University of California Press.

Polan, Dana 1986 Power and Paranoia: History, Narrative, and the American Cinema, 1940-1950. New York: Columbia University Press.

Reid, David 1997 'The Rains of Empire: Camus in New York,' MLN 112: 608-624.

Said, Edward 1993 Culture and Imperialism. London: Chatto \& Windus.

Sartre, Jean-Paul 2008 The Aftermath of War (Situation III), trans. Chris Turner. London and New York: Seagull Books.
2001 'From One China to Another' in Colonialism and NeoColonialism, trans. Azzedine Haddour, Steve Brewer and Terry McWilliams. London and New York: Routledge, pp.17-29.

2000 'What is Writing?' trans. Bernard Frechtman in Clive Cazeaux, ed. The Continental Aesthetics Reader (London: Routledge), pp.101-116 (115).

1987 (1972) 'Make Illness a Weapon,' Journal of the British Society for Phenomenology 18/1 (January): 3-5.

1966 'The Situation of the Writer in 1947', in What Is Literature?, trans. Bernard Frechtman. New York: Washington Square Press.

1946 'American Novelists in French Eyes', Atlantic Magazine 178 (August): 114-18.

Smith, Douglas 2009 'From One China to the Other: Cartier-Bresson, Sartre and Photography in the Age of Decolonization,' Photographies 2/1 (March): 59-71.

Todd, Olivier 1996 Albert Camus: Une Vie. Paris: Gallimard.

Wald, Priscilla 2008 Contagious: Cultures, Carriers, and the Outbreak Narrative. Durham, NC: Duke University Press.

Ward, David and Oliver Zunz, eds. 1992 The Landscape of Modernity: New York City, 1900-1940. Baltimore, MD: Johns Hopkins University Press. 
